\title{
Dakwah Ulama Tentang Zakat Pertanian Di Kecamatan Anjir Pasar Kabupaten Barito Kuala.
}

Oleh: Rina dan Syuhada

\begin{abstract}
Abstark
Tujuan Penelitian ini adalah; Untuk mengetahui pandangan ulama tentang zakat pertanian, materi, Metode yang disampaikan dan digunakan oleh ulama pada masyarakat Kecamatan Anjir Pasar Kabupaten Barito Kuala. Dakwah Ulama tentang Zakat Pertanian di Kecamatan Anjir Pasar Kabupaten Barito Kuala, adalah ; Para ulama sepakat bahwa zakat pertanian, khususnya padi, hukumnya adalah wajib. Tetapi mereka berbeda pendapat tentang jumlah belik padi yang wajib dizakati. Sebagian berpendapat apabila padi sudah sampai 100 belik maka wajib dizakati. Yang lainnya berpendapat kalau padi sudah sampai 85 belik maka wajib dizakati. Kemudian ada juga yang berpendapat bahwa kalau padi sudah sampai 84 belik baru wajib dizakati. Namun mereka semua berpendapat bahwa jumlah zakat yang dikeluarkan adalah $10 \%$. Materi Dakwah yang disampaikan para Ulama di Kecamatan Anjir Pasar tentang zakat pertanian tidak terlepas dari hukum-hukumnya serta bagianbagiannya, seperti takaran wajib pemberian zakat ataupun orang-orang yang berhak menerima zakat tersebut. Terkait materi tersebut, kemudian beberapa ulama juga menjelaskan bahwa selain menyampaikan materi terkait zakat pertanian, mereka juga menyampaikan materi-materi yang lain, seperti kewajiban sholat dan lain-lain. Metode dakwah para Ulama dalam penyampaian materi tentang zakat pertanian tersebut biasanya dilaksanakaan oleh para ulama dengan dua metode yang digunakan yaitu metode dakwah bil lisan dan dakwah bil Hikmah. Dakwah bil lisan seperti ceramah mingguan ataupun bulanan biasanya dilakukan oleh Ulama dalam kesempatan tertentu seperti pengajian rutin, majelis ta'lim maupun undangan-undangan acara di masyarakat. Selain itu dalam acara-acara besar tentu juga diisi dengan ceramah-ceramah agama. Dalam kesempatan lain juga disampaikan materi dakwah dengan metode bil lisan seperti dalam Khutbah

Jum'at.

Kata Kunci : Ulama, Metode Dakwah, Zakat.
\end{abstract}

\section{A. Pendahuluan}

Dakwah pada dasarnya penyampaian ajaran Islam kepada manusia baik secara lisan maupun dalam bentuk sikap dan perilaku diarahkan supaya timbul kesadaran dan mengamalkan setiap esensi ajaran Islam. Penyampaian dakwah dapat dilakukan dimana-mana, dari lingkup yang sangat kecil sampai lingkup yang sangat besar. Salah satunya kepada masyarakat Kecamatan Anjir Pasar Kabupaten Barito Kuala.

Salah satu kelompok masyarakat yang berperan penting dalam menyampaikan pesan-pesan keagamaan adalah para ulama. Itulah sebabnya, perkataan ulama sudah tidak asing lagi, malah bisa di bilang begitu popular dikalangan masyarakat, mulai dari kategori menengah ke bawah hingga kalangan elit. Di berbagai strata sosial, masyarakat kenal betul dengan yang namanya ulama. Lebih dari itu lagi kata "ulama" itu sendiri sudah baku menjadi kosa kata bahasa Indonesia. Padahal perkataan "ulama" itu merupakan kata pungutan dari bahasa asing (Arab).

Menurut Djalimis Syah dalam Kamus Pelajar Kata Serapan Bahasa Indonesia, ulama berarti orang yang ahli dalam hal atau dalam pengetahuan agama Islam. Bila dilihat dari perspektif kaidah 
bahasa Arab, maka bisa dikatakan bahwa ulama merupakan bentuk jamak dari mufrad atau kata tunggal dari alim. Alim itu sendiri adalah isim fail dari kata kerja alima. Karena itu berarti ia orang yang mengerti, yang berilmu atau orang yang berpengetahuan. (Makkie H.A, 2010: 5)

Harun Nasution dalam buku Ensiklopedi Islam merumuskan bahwa ulama adalah orang yang mendalami ilmu pengetahuannya, baik ilmu pengetahuan yang bersumber dari Allah SWT yang kemudian disebut ulumuddin, maupun ilmu pengetahuan yang bersumber dari hasil penggunaan potensi akal dan indra manusia dalam memahami ayat-ayat kauniyah yang kemudian disebut ulumul insaniyah atau al-ulum (sains).(Ibid : 8)

Atas dasar pengertian di atas, baik secara etimologi maupun terminologi, maka secara sederhana hakikat arti dan makna ulama tersebut pada prinsipnya adalah mereka yang betul-betul berilmu pengetahuan, bahkan menguasainya terutama ilmu agama, mempunyai wawasan yang luas tentang Islam dan seluk beluknya, konsekuen dan komitmen dengan ilmu dan wawasannya itu, mengamalkan secara profesional.

Posisi ulama dalam kehidupan masyarakat mempunyai peran yang sangat penting terutama dilingkungan di mana ulama itu berdomisili. Ulama memang menjadi tempat bertanya, meminta fatwa, minimal meminta advis (masukan) dan nasehat keagamaan. Oleh karena itu mereka dituntut agar selalu tampil sebagai referensi masyarakat atau acuan umat, bahkan sebagai figur sentral yang layak dijadikan cerminan dan panutan. (Ibid : 11)

Di manapun ulama berada, sudah seharusnya mereka menjadi sosok panutan, figur teladan, maupun acuan umat dan bahkan sebagai pembimbing sekaligus pemimpin masyarakat. Termasuk di dalamnya peran di dalam menyampaikan mengkomunikasikan pesan dan materi agama, misalnya berkenaan dengan zakat pertanian dan segala dinamika yang terjadi di dalamnya.

Zakat hasil pertanian adalah salah satu jenis Zakat Maal, obyeknya meliputi hasil tumbuh-tumbuhan atau tanaman yang bernilai ekonomis seperti biji-bijian, umbi-umbian, sayur-mayur, buah-buahan, tanaman hias, rumputrumputan, dedaunan, dan lain-lain. Banyaknya sepersepuluh dari hasil panen bila pengairannya tidak membutuhkan biaya dan seperdua puluh bila pengairannya membutuhkan biaya. Maka seharusnya zakat profesi juga harus demikian, tidak dipungut $2,5 \%$ agar qiyas ini lurus dan tidak aneh. ( M. Ali Hasan, 2006 : 50).

Zakat dalam konsep Islam digunakan dalam rangka menjalankan hukumhukum Islam dengan benar, dan membayar zakat termasuk dalam rukun Islam yang ke 4 yang bisa di gunakan untuk membersihkan harta dan mensucikan diri karena diwajibkan berzakat bagi yang mampu dengan memberikan sebagian harta kepada orang yang berhak menerimanya. ( MA Sudirman, 2007 : 5)

Karena itu, pemberdayaan masyarakat petani yang perlu dilakukan dalam menyikapi kemiskinan ini adalah dengan mendorong masyarakat untuk menyadari bahwa sektor pertanian adalah sektor kebutuhan yang paling vital bagi masyarakat Anjir. instansi pemerintah serta swasta lainnya.

Pendekatan khusus dengan upaya menyadarkan masyarakat petani untuk membayar zakat dengan keterlibatan ulama dalam menyampaikan pesan keagamaan sangat penting untuk dilakukan. Aktivitas untuk menumbuhkan kesadaran dan memicu pemahaman masyarakat terhadap signifikansi dan optimalisasi pemberdayaan zakat, tentu saja terkait banyak dengan aktivitas komunikasi.

Berdasarkan latar belakang tersebut peneliti tertarik melakukan penelitian yang penulis tuangkan dalam bentuk skripsi dengan judul "Dakwah Ulama 
Tentang Zakat Pertanian di Kecamatan Anjir Pasar Kabupaten Barito Kuala”.

\section{B. Tujuan Penelitian}

Berdasarkan latar belakang dan rumusan masalah di atas, maka penelitian ini dilakukan dengan rujukan sebagai berikut:

1. Untuk mengetahui pandangan ulama tentang zakat pertanian di Kecamatan Anjir Pasar Kabupaten Barito Kuala.

2. Untuk mengetahui materi tentang zakat pertanian yang pernah disampaikan oleh ulama pada masyarakat Kecamatan Anjir Pasar Kabupaten Barito Kuala.

3. Untuk mengetahui metode yang digunakan oleh Ulama dalam menyampaikan ajaran tentang zakat pertanian kepada masyarakat di Kecamatan Anjir Pasar Kabupaten Barito Kuala.

\section{Gambaran \\ Penelitian \\ 1. Letak geografis}

Umum

Lokasi

Luas Wilayah Kecamatan Anjir Pasar mencapai $126 \mathrm{Km}^{2}$. Batas Wilayah Kecamatan Anjir Pasar meliputi: di sebelah Utara dengan Kecamatan Belawang atau Wanaraya, di sebelah Selatan dengan kecamatan Tamban dan Mekarsari, di sebelah Timur dengan Kabupaten Kapuas (Provinsi Kalteng).

Kecamatan Anjir Pasar terdapat terusan atau kenal buatan (Anjir) yang menghubungkan Sungai Barito dengan Sungai Kapuas, yaitu Anjir Serapat. Kota Anjir Pasar sebagai Ibukota Kecamatan berjarak $\pm 40 \mathrm{Km}^{2}$ dari Ibukota Kabupaten Barito Kuala, dan Banjarmasin (Ibukota Provinsi Kalimantan Selatan) berjarak $\pm 25 \mathrm{Km}$ serta ke Ibukota Kabupaten Kapuas (Provinsi Kalimantan Tengah) berjarak \pm $20 \mathrm{Km}$ yang dapat ditempuh melalui jalan darat maupun melalui sungai.

Secara geografis, Kecamatan Anjir Pasar terletak pada lingkup koordinat 114 20" 50" sampai dengan 114 20" 8" Lintang Selatan dan 2 29" 50" sampai dengan 3 30' Bujur Timur. Wilayah Kecamatan Anjir Pasar seluas 126.00 atau hanya $4.2 \%$ dari luas wilayah Barito Kuala.

Luas wilayah Kecamatan Anjir Pasar menurut kelas kelerengan/kemiringan termasuk dalam kemiringan 0-2 \%. Luas wilayah kecamatan Anjir Pasar menurut kelas ketinggian dari permukaan adalah 0-2 M.

TABEL 1: Pembagian Wilayah Administrasi Pemerintah Kecamatan Anjir Pasar

\begin{tabular}{|c|c|c|c|}
\hline No & Desa & $\begin{array}{l}\text { Luas } \\
\text { Wilayah } \\
\left(\mathbf{K m}^{2}\right)\end{array}$ & $\begin{array}{l}\text { Jumlah } \\
\text { RT }\end{array}$ \\
\hline 1. & Andaman & 8 & 10 \\
\hline 2. & Hilir Mesjid & 6,5 & 6 \\
\hline 3. & $\begin{array}{l}\text { Anjir Pasar Kota } \\
1\end{array}$ & 4,62 & 6 \\
\hline 4. & Banyiur & 16,74 & 6 \\
\hline 5. & Gandaraya & 9,25 & 4 \\
\hline 6. & Gandaria & 11,37 & 6 \\
\hline 7. & Kota II & 8,67 & 14 \\
\hline 8. & Andaman II & 9,50 & 11 \\
\hline 9. & $\begin{array}{l}\text { Anjir Seberang } \\
\text { Pasar II }\end{array}$ & 11,25 & 9 \\
\hline 10. & $\begin{array}{l}\text { Anjir Seberang } \\
\text { Pasar }\end{array}$ & 11,25 & 8 \\
\hline 11. & Anjir Pasar Lama & 11,00 & 8 \\
\hline 12. & Pandan Sari & 3,75 & 8 \\
\hline 13. & Mantaren & 3,00 & 5 \\
\hline 14. & Barunai Baru & 3,50 & 4 \\
\hline \multirow[t]{2}{*}{15.} & Danau Karya & 7,60 & 7 \\
\hline & Jumlah & 126 & 110 \\
\hline
\end{tabular}

Sumber: Badan Pusat Statistik
Kabupaten Barito Kuala

Dari segi penggunaan tanah terlihat bahwa untuk lahan sawah 8.049 ha atau $63.68 \%$, pertanian non sawah 2.166 ha atau $17.19 \%$ sedangkan untuk lahan perumahan hanya 2.385 ha atau $18.19 \%$ dari luas wilayah Kecamatan.

Kecamatan Anjir Pasar termasuk daerah hujan tipe B yaitu iklim yang 
mempunyai 1-2 bulan kemarau dalam setahun. Curah hujan di suatu tempat antara lain dipengaruhi oleh keadaan iklim dan perputaran arus udara. Oleh karena itu curah hujan beragam menurut bulan dan letak stasiun pengamat. Di Kecamatan Anjir Pasar berdasarkan stasiun pengamatan Anjir pasar, rata-rata curah hujan selama tahun 2012 adalah $16.30 \mathrm{~mm} /$ hari dimana rata-rata curah hujan tertinggi adalah pada bulan Desember yakni $24.43 \mathrm{~mm}$ per hari.

Temperatur rata-ratanya antara 2527 derajat celcius, dengan suhu maksimum 27,50 C (bulan Oktober) suhu minimum 26,50 C (bulan Juli). Sedangkan angka rata-rata hujan setiap tahunnya adalah 2,605 $\mathrm{mm}$ dengan 107 hari hujan. Dengan karakteristik lahan dengan ketinggian 2-4 mdpl: kemiringan $2 \%$ kedalaman lapisan atas tanah (top soil) $10 \mathrm{~cm}$; kesuburan tanah rata-rata sedang.

\section{Demografis}

Pada akhir Desember 2008, penduduk Kecamatan Anjir Pasar berjumlah 16.303 jiwa dengan penduduk laki-laki berjumlah 8.086 jiwa dan perempuan berjumlah 8.127 jiwa dengan pertumbuhan penduduk sebesar $2 \%$ pertahun dengan jumlah Kepala Keluarga 4.197 KK.

TABEL 2: Jumlah Penduduk Kecamatan Anjir Pasar

\begin{tabular}{|l|l|c|l|l|}
\hline No & \multicolumn{1}{|c|}{ Desa } & \multicolumn{3}{|c|}{$\begin{array}{c}\text { Penduduk akhir bulan } \\
\text { ini }\end{array}$} \\
\cline { 3 - 5 } & & Lk & \multicolumn{1}{|c|}{ Pr } & Lk+Pr \\
\hline 1. & $\begin{array}{l}\text { Anjir Pasar } \\
\text { Kota }\end{array}$ & 773 & 803 & 1576 \\
\hline 2. & $\begin{array}{l}\text { Anjir Pasar } \\
\text { Kota II }\end{array}$ & 941 & 905 & 1846 \\
\hline 3. & $\begin{array}{l}\text { Anjir Pasar } \\
\text { Lama }\end{array}$ & 964 & 1100 & 2064 \\
\hline 4. & $\begin{array}{l}\text { Anjir } \\
\text { Seberang } \\
\text { Pasar I }\end{array}$ & 666 & 687 & 1353 \\
\hline 5. & $\begin{array}{l}\text { Anjir } \\
\text { Seberang } \\
\text { Pasar II }\end{array}$ & 654 & 692 & 1346 \\
\hline 6. & Andaman II & 645 & 638 & 1283 \\
\hline 7. & Andaman & 616 & 629 & 1245 \\
\hline
\end{tabular}

\begin{tabular}{|l|l|l|l|l|}
\hline 8. & $\begin{array}{l}\text { Pandan } \\
\text { Sari }\end{array}$ & 287 & 266 & 553 \\
\hline 9. & Hilir Mesjid & 629 & 660 & 1289 \\
\hline 10. & $\begin{array}{l}\text { Barunai } \\
\text { Baru }\end{array}$ & 425 & 453 & 877 \\
\hline 11. & Banyiur & 547 & 577 & 1124 \\
\hline 12. & Gandaria & 358 & 359 & 717 \\
\hline 13. & Bandaraya & 263 & 274 & 537 \\
\hline 14. & Mantaren & 287 & 267 & 554 \\
\hline 15. & $\begin{array}{l}\text { Danau } \\
\text { Karya }\end{array}$ & 274 & 235 & 509 \\
\hline & Jumlah & $\mathbf{8 3 2 8}$ & $\mathbf{8 5 4 5}$ & $\mathbf{1 6 8 7 3}$ \\
\hline
\end{tabular}

Sumber. Biro Pusat Statistik Kabupaten Barito Kuala

Dari jumlah penduduk tersebut dengan latar pendidikan sebagai berikut:

a. Tidak tamat SD $3 \%$

b. Tamat SD/SLTP $55 \%$

c. Tamat SLTA $35 \%$

d. Tamat Akademi/PT $7 \%$

TABEL 3: Nama-nama Tokoh Agama dan Ulama Kecamatan Anjir Pasar

\begin{tabular}{|l|l|l|}
\hline NO & \multicolumn{1}{|c|}{ NAMA } & \multicolumn{1}{c|}{ TEMPAT } \\
\hline 1 & Norfansyah & Barunai Baru \\
\hline 2 & Drs. Baderun & Barunai Baru \\
\hline 3 & $\begin{array}{l}\text { Ny. Elpi Nurhida } \\
\text { Rusyadi }\end{array}$ & Barunai Baru \\
\hline 4 & $\begin{array}{l}\text { H. } \\
\text { Fathurrahman }\end{array}$ & Hilir Masjid \\
\hline 5 & H. Rasyidi & Hilir Masjid \\
\hline 6 & H. Mansyah & Hilir Masjid \\
\hline 7 & $\begin{array}{l}\text { K.H. Muhammad } \\
\text { Baderi }\end{array}$ & Anjir Pasar Kota I \\
\hline 8 & $\begin{array}{l}\text { H. M. Syarkawi } \\
\text { Masdar }\end{array}$ & Anjir Pasar Kota II \\
\hline 9 & Syukeri & Pandan Sari \\
\hline 10 & H. Napiah & Andaman I \\
\hline 11 & Asiah & Andaman I \\
\hline 12 & Junaidi, S.Pd.I & Andaman II \\
\hline 13 & Juhriansyah & Banyiur \\
\hline 14 & Syarkowi & Gandaria \\
\hline 15 & Aliansyah & Mantaren \\
\hline 16 & $\begin{array}{l}\text { H. Abdullah } \\
\text { Syarkawi }\end{array}$ & Anjir Pasar Lama \\
\hline 17 & H. Syahran & Anjir Pasar Kota I \\
\hline 18 & Hamzah & Anjir Pasar Lama \\
\hline 19 & Mursidah, S.Ag & Anjir Pasar Lama \\
\hline 20 & H. Mansur & Anjir Pasar Lama \\
\hline 21 & Artom Ali S.Ag & $\begin{array}{l}\text { Anjir Seberang } \\
\text { Pasar I }\end{array}$ \\
\hline 22 & Jahwariah,S.Ag & $\begin{array}{l}\text { Anjir Seberang } \\
\text { Pasar I }\end{array}$ \\
\hline
\end{tabular}




\begin{tabular}{|l|l|l|}
\hline 23 & H.Sayuthi & $\begin{array}{l}\text { Anjir Seberang } \\
\text { Pasar I }\end{array}$ \\
\hline 24 & H.Rusli & $\begin{array}{l}\text { Anjir Seberang } \\
\text { Pasar II }\end{array}$ \\
\hline 25 & H. M. Zaini & $\begin{array}{l}\text { Anjir Seberang } \\
\text { Pasar II }\end{array}$ \\
\hline 26 & Akhmad Rafi'i & Anjir Pasar Lama \\
\hline
\end{tabular}

Sumber: Kantor Urusan Agama (KUA) Kecamatan Anjir Pasar

Data pekerjaan yang dapat terhimpun berdasarkan pendataan keluarga hanya berdasarkan KK yang tidak bekerja.

a. KK yang tidak bekerja sebanyak 5 $\%$

b. KK yang bekerja sebanyak $95 \%$

Agama di Kecamatan Anjir Pasar lebih dari $95 \%$ beragama Islam yang taat dalam beribadah, dimana tempat peribadatan terdapat 7 buah mesjid dan 55 buah langgar dan Mushalla. Dalam upaya menyemarakkan dan menyebar luaskan festival syair Maulid Al-Habsy yang sudah menjadi agenda tahunan yaitu dalam rangka memperingati tahun baru Islam dan hari jadi Kabupaten Barito Kuala.

\section{PENYAJIAN DATA}

Dari penelitian yang penulis lakukan, dapat diuraikan dan dipaparkan beberapa hasil sebagai berikut:

\section{Pandangan Ulama Kecamatan Anjir Pasar tentang Zakat Pertanian}

Kelima juru Dakwah berpendapat bahwa jenis hasil pertanian yang wajib dizakati khusus untuk di daerah Kecamatan Anjir Pasar adalah padi. Namun mereka berbeda pendapat tentang jumlah beliknya. H. Abdullah Syarkawi, H. M. Syarkawi Masdar dan Norfansyah sama-sama berpendapat bahwa kalau padi sudah sampai 100 belik maka wajib dizakati, sedangkan menurut Ahmad Rafi'i kalau padi sudah sampai 85 belik maka wajib dizakati, dan menurut $H$. Rasyidi berpendapat bahwa kalau padi sudah sampai 84 belik baru bisa wajib dizakati. Namun mereka semua berpendapat bahwa jumlah zakat yang dikeluarkan adalah $10 \%$.
Menurut para ulama hitungan zakat pertanian di Kecamatan Anjir Pasar kalau 1 belik padi itu sama dengan 20 liter padi atau $20 \mathrm{~kg}$ padi. Jadi kalau 100 belik padi sama dengan $2000 \mathrm{~kg}$ padi, maka wajib zakatnya adalah 200 kg padi.

Adapun jenis pertanian seperti bijibijian khususnya untuk di daerah Kecamatan Anjir dengan mayoritas penghasil pertanian padi, hal ini dipaparkan oleh salah satu responden. Beliau menyebutkan dalam wawancara bahwa: Jenis zakat pertanian yang perlu di zakati adalah biji-bijian yang wajib di zakati, seperti di anjir padi, kalau di Arab gandum. Banyak atau persen dari hasil pertanian tersebut yang wajib dikeluarkan zakatnya kalau 84 belik yang paling mu'tamat wajib 10 $\%$. Padi itu wajib dizakati. Zakat padi yang irigasi atau tadah hujan berbeda kalau tadah hujan 10\% kalau irigasi kurang tau karena itu ada hitungan pakai biaya. Nisab zakat hasil pertanian itu $10 \%$.

Dari pendapat diatas beliau menyebutkan tentang hukum mengeluarkan zakat, jenis pertanian yang perlu dizkatai, dalam pendapat lain juga disebutkan mengenai hal tersebut seperti yang disampaikan oleh Ustadz H. Abdullah Syarkawi: Hasil pertanian yang wajib di zakati adalah padi, gandum, palawija, anggur, korma. Tapi kalau di Kecamatan Anjir padi saja hasil pertanian yang dizakati. Kalau hasil pendapatan 100 belik maka wajib zakat $10 \%$. Jadi padi itu wajib zakat. Zakat padi Irigasi atau tadah hujan berbeda karena irigasi memakai biaya jadi $5 \%$ saja zakatnya, kalau tadah hujan $10 \%$ karena tidak memerlukan biaya. Nisab zakat padi satu haul setahun sekali pendapatan. Orang yang berhak memperoleh zakat pertanian adalah orang delapan seperti Fakir, Fakir miskin, Bukhora, Amil, mu'alaf, budak, ibnu sabil dan Ganim.

Namun mereka berbeda pendapat dengan jumlah beliknya. Menurut $\mathrm{H}$. Abdullah Syarkawi, H. M. Syarkawi Masdar dan Norfansyah sama-sama 
berpendapat bahwa kalau padi sudah sampai 100 belik maka wajib dizakati, sedangkan menurut Ahmad Rafi'i kalau padi sudah sampai 85 belik maka wajib dizakati, dan menurut $H$. Rasyidi berpendapat bahwa kalau padi sudah sampai 84 belik baru bisa wajib dizakati. Namun mereka semua berpendapat bahwa jumlah zakat yang dikeluarkan adalah $10 \%$ adalah: Memanfaatkan hasil zakat pertanian, menurut Ustadz H. Abdullah Syarkawi, bisa untuk modal dan untuk makan sehari-hari. Tuan guru atau ulama berhak menerima zakat karena orang yang memperjuangkan agama, kalau tidak ada tuan guru, otomatis tidak ada yang menyampaikan dakwah.

Tentang amil zakat, menurut Ustadz H. Abdullah Syarkawi, yang menjadi Amil adalah BAZ (Badan Amil Zakat) dan KUA (Kantor Urusan Agama) yang bisa ditunjuk dari KUA kampung lingkungannya. Amil tidak perlu mendapat izin dari pemerintah, yang penting ada SK nya untuk membagi zakat kepada faqir miskin. Memberikan zakat kepada mustahik tanpa melalui amil boleh saja. Berzakat dengan keluarga boleh saja, karena dalam AlQur'an, keluarga dulu yang di utamakan. Mazhab yang biasanya di pakai oleh beliau dalam bidang zakat adalah mazhab Imam Syafi'i.

Ustadz H. Muhammad Syarkawi Masdar, kata beliau di daerah Anjir Padi saja yang perlu di zakati, hasil dari pertanian minimal 100 belik atau 90 belik zakatnya $10 \%$. Jadi padi itu wajib dizakati. Zakat padi yang irigasi atau tadah ujan itu berbeda kalau irigasi $5 \%$ sementara tadah hujan $10 \%$.

Menurut Ustadz H. Muhammad Syarkawi Masdar, yang berhak memperoleh zakat hasil pertanian adalah orang yang 8 seperti yang disebutkan Ustadz sebelumnya. Memanfaatkan zakat hasil pertanian bisa dimodal untuk dagang dan untuk makan sehari-hari yang jelas diserahkan pada masyarakat miskin, pondok juga berhak, seperti pondok pesantren Darussalam, Al-Fallah dan lain-lain itu orang-orang sabilillah. Tuan guru atau ulama berhak menyampaikan dakwah kata Husin Nafarin termasuk Bilal, Khatib dan Imam, kalau ulama produktif yang menyamaikan agama, kecuali ulama itu bergadang atau kaya beliau bisa tidak menerima zakat.

Mengenai amil zakat yang boleh menjadi amil untuk zakat pertanian itu bebas saja atau bagian BAZ menunjuk amil yang membagikan kepada fakir miskin. Amil harus mendapat izin dari pemerintah. Memberikan zakat kepada mustahik secara langsung tanpa melalui amil boleh saja langsung, berhak menerima mustahik, pelajar atau santri. Berzakat dengan keluarga boleh asalkan termasuk fakir atau miskin keluarganya. Mazhab yang biasanya di pakai beliau adalah mazhab syafi'i.

Ustadz Ahmad Rafi'i kata beliau yang perlu di zakati adalah padi, buahbuahan, anggur dan kurma. Banyak atau persen dari hasil pertanian tersebut yang wajib dikeluarkan zakatnya kalau 85 belik sudah sampai zakatnya $10 \%$. Padi harus wajib dizakati. Zakat padi yang irigasi atau tadah hujan itu berbeda, kalau irigasi wajib zakatnya $5 \%$ karena memerlukan biaya seperti pompa air, sedangkan tadah hujan $10 \%$. Nisab zakat hasil pertanian $10 \%$.

Menurut Ustadz Ahmad Rafi'i, yang berhak memperoleh zakat hasil pertanian yang termasuk orang delapan, itu yang lebih diutamakan. Memanfaatkan zakat hasil pertanian untuk kebutuhan sehari-hari yang lebih memerlukan atau bisa juga dimodalkan. Tuan guru atau ulama berhak menerima zakat pertanian karena ulama termasuk fii sabilillah.

Mengenai yang boleh menjadi amil atau pengumpul zakat untuk zakat pertanian bisa panitia mesjid, penghulu, KUA (Kantor Urusan Agama), BAZ (Badan Amil Zakat). Amil harus mendapat izin dari pemerintah. Mereka bisa menerima zakat yang disetorkan dari panitia di kampung Memberikan 
zakat kepada mustahik secara langsung tanpa melalui amil boleh saja apabila udah sampai musim panen. Berzakat dengan keluarga boleh, seperti saudara terdekat yang tidak mampu. Mazhab yang biasanya dipakai para ulama ketika membahas tentang pelaksanaan zakat pertanian di Kecamatan Anjir adalah mazhab Imam Syafi'i.

Menurut ustadz H. Rasyidi, yang berhak memperoleh zakat hasil pertanian termasuk orang yang 8 itu. Pemanfaatan zakat hasil pertanian harus dengan niat yang ikhlas. Tuan guru atau ulama berhak menerima zakat pertanian. Namun sebenarnya mereka tidak berhak karena kebanyakan ulama sudah mampu. Yang boleh menjadi amil atau pengumpul zakat untuk zakat pertanian bisa bagian BAZ. Amil harus mendapat izin dari pemerintah, terutama izin pemerintah setempat.

Mengenai orang yang berhak menerima zakat, menurut Ustadz $\mathrm{H}$. Rasyidi, adalah yang termasuk golongan 8. Pemberian zakat kepada mereka bisa secara langsung tanpa melalui amil boleh. Berzakat kepada keluarga yang mampu tidak boleh. Tidak boleh berzakat lewat janji. Mazhab yang biasanya dipakai para ulama ketika membahas tentang pelaksanaan zakat pertanian di Kecamatan Anjir adalah mazhab Syafi'i dan mazhab Hanafi. Kedua mazhab itu membolehkan pemberian zakat langsung kepada mustahik tanpa melalui amil.

Menurut Ustadz Norfansyah, yang wajib dizakati adalah padi atau beras, jagung dan gandum, buah-buahan kurma dan anggur. Apabila padi sudah mencapai 100 belik maka wajib dizakati $10 \%$ (10 belik). Padi wajib dizakati. Ada perbedaan antara padi yang airnya berasal dari irigasi dan tadah hujan. Kalau irigasi $5 \%$ sedangkan tadah hujan $10 \%$, karena tadah hujan tidak memakai biaya.

Ustadz Norfansyah berpendapat yang berhak memperoleh zakat hasil pertanian adalah golongan mustahik yang 8. Pemanfaattan zakat hasil pertanian adalah untuk mengangkat derajat kaum du'afa. Tuan guru atau ulama termasuk yang berhak menerima zakat pertanian.

Semua orang yang bisa membentuk panitia amil zakat boleh mengumpulkan zakat hasil pertanian. Amil yang mendapat izin dari pemerintah maupun yang tidak mendapat izin boleh mengumpulkan zakat. Memberikan zakat kepada mustahik secara langsung tanpa melalui amil boleh. Berzakat kepada keluarga boleh. Mazhab yang biasanya dipakai para ulama ketika membahas tentang pelaksanaan zakat pertanian di Kecamatan Anjir adalah mengikuti (bertaklid), mazhab Abu Hanifah.

\section{Materi Dakwah yang Disampaikan Ulama tentang Zakat Pertanian}

Dari hasil penelitian dikemukakan bahwa materi atau pesan-pesan keagamaan yang disampaikan oleh para Ulama kecamatan Anjir Pasar tentu tidak terlepas mengena kewajiban berzakat, seperti yang disampaikan oleh salah satu responden dalam wawancara sebagai berikut:

Paling sering menyampaikan tentang kewajiban zakat, dan orang-orang yang menerima zakat. Wajib apabila sudah sampai nisabnya, karena kalau tidak disampaikan tentang penting nya berzakat dikhawatirkan ada yang lalai atau enggan berzakat, seperti yang kita lihat masyarakat anjir berzakat sesuai dengan tuntunan ajaran Islam.

Disampaikan oleh Ulama Ahmad Rafi'i beliau menjawab: "biasanya menyampaikan tentang apabila sampai nisabnya dan haulnya (harta) wajib zakat, kenapa perlu dismpaikan tentang zakat agar masyarakat sadar pentingnya berzakat. Sudah benar saja cara masyarakat anjir dalam berzakat". Namun demikian selain mengenai kewajiban berzakat, salah satu ulama juga mengatakan bahwa selain menyampaikan meteri terkait zakat beliau juga menyampaikan materi lain seperti kewajiban melaksanakan sholat, hal ini disampaikan dalam wawancara 
pada hari Sabtu, tanggal 23 Februari 2012

Ustadz H. Abdullah Syarkawi ketika ditanya tentang materi yang di sampaikan kepada masyarakat tentang zakat padi, beliau menjawab: "berbedabeda tidak khusus tentang zakat, masalah sembahyang, melihat situasi yang hadir pembacaan ketika ceramah disampaikan. Sebabnya kalau kita menyampaikan tentang zakat orang bisa dulak jua." Maksudnya selain menyampaikan tentang zakat juga ceramah materi tentang sholat, melihat situasi yang hadir apabila beliau menyampaikan tentang zakat saja orang bisa bosan juga. Ceramah itu biasanya beliau sampaikan di berbagai tempat ketika di mesjid, musholla, undanganundangan di rumah masyarakat.

Selain menyampaikan tentang zakat juga ceramah materi tentang sholat, melihat situasi yang hadir apabila kita menyampaikan tentang zakat saja orang bisa bosan juga. Ceramah itu biasanya beliau sampaikan di berbagai tempat ketika di mesjid, musholla, undanganundangan di rumah masyarakat". Beliau memiliki sawah pertanian, kalau ada anggota masyarakat yang tidak mau berzakat, tidak di paksaakan, tanggung jawab masing-masing. Kalau ada amil yang menyelewengkan itu juga tanggung jawab amil masing-masing yang penting hukum berzakat sudah disaampaikan.

Ustadz Ahmad Rafi'i ketika ditanya tentang materi yang disampaikan kepada masyarakat tentang zakat padi, beliau menjawab:

Ada aja disampaikan, kadang-kadang ada juga masyarkat bertanya tentang zakat padi ketika musim panen. Ceramah biasanya di berbagai-bagai tempat ketika di majelis ta'lim, di mesjid, di undangan masyarakat. Ada saja mempunyai sawah pertanian, masyarakat yang tidak mau berzakat harus diberi tau dan bagaimana dari segi hukum agamanya. Amil yang menyelewengkan di beri nasehat dulu.

Dalam penelitian ini salah satu ulama mengatakan bahwa setiap ulama menyampaikan ceramah tentang zakat pertanian, biasanya ada masyarakat yang masih kurang paham tentang zakat pertanian langsung konsultasi ke rumah ulama untuk bertanya tentang masalah zakat.

Ustadz Norfansyah ketika ditanya tentang materi dakwah tentang zakat yang disampaikan, beliau menjawab:

Bisa aja saat acara-acara membahas tentang zakat pertanian, ada juga menyampaikan tentang fiqih Islam dan qaidah Islam. Ceramah ada saat menghadiri undangan-undangan, majelis ta'lim di mesjid atau di musholla". Saya ada mempunyai sawah pertanian, masyarakat yang tidak mau berzakat bisa melalui ceramah di himbau untuk berzakat. Kalau ada amil yang menyelewengkan hasil dari pengumpulan zakat itu sendiri bisa ditindak atau melalui pendekatan.

Ustadz H. Rasyidi ketika ditanya tentang materi dakwah yang beliu sampaikan mengenai zakat pertanian, beliau menjawab:

Ada aja biasanya di dalam kitab Fiqih sebagian besar membahas tentang zakat pertanian, sifat-sifat 20 Tauhid dan masalah hukum Zakat Pertanian, Kitab Mazahibur Arba'a dan Kitab Sabilal Muhtadin tentang masalah wudhu dan masalah nikah. Biasanya ceramah di Majelis, undanganundangan acara Isra Miraj dan Bulan maulid. Ada memiliki sawah pertanian, tapi disewakan jadi menerima hasilnya saja. Kalau ada anggota masyarakat yang tidak mau berzakat di jelaskan masalah hukum zakat, masalah nisab, harta yang dizakati, di beri pengarahan dan di beri ancaman. Kalau ada amil yang menyelewengkan hasil zakat pertanian diberi teguran atau penjelasan, di beri ancaman dan bisa diberhentikan.

\section{Metode Dakwah Ulama tentang Zakat Pertanian}

Dari wawancara yang penulis lakukan selama penelitian, didapatkan hasil bahwa Metode yang banyak digunakan oleh kelima responden/juru dakwah atau Ulama dalam penelitian ini 
adalah metode dakwah bil Lisan dan metode dakwah bil hikmah.

\section{Metode Dakwah Bil Lisan.}

Metode Dakwah bil lisan ini digunakan oleh semua juru Dakwah/ Ulama yang menjadi informen dalam menyampaikan pesan-pesan keagamaan baik terkait zakat maupun berbagai materi lain kepada masyarakat khususnya masyarakat Anjir Pasar. Metode bil lisan ini biasanya digunakan oleh ulama Anjir Pasar dalam ceramahceramah agama, khutbah jum'at, acara pengajian-pengajian, selain itu penyampaian dakwah bil lisan juga digunakan pada acara undanganundangan oleh masyarakat.

Hal ini disampaikan dibenarkan oleh salah satu responden dalam wawancara ketika ditanya tentang metode yang disampaikan kepada masyarakat tentang zakat padi, Ustadz H. M. Syarkawi Masdar beliau menjawab:

Biasanya ada saja menyampaikan tentang zakat padi, karena itu kewajiban ulama untuk menyampaikan. Biasanya sampaikan di berbagai-bagai tempat ketika di majelis ta'lim, di sekolahan-sekolahan, undangan di rumah masyarakat, dan undangan arisan, pada kesempatan bulan rajab dan bulan maulid". Saya ada sawah pertanian karena mulai lagi kecil ikut orang tua bertani. Yang tidak mau berzakat di beri nasehat dan diterangkan sanksi-sanksinya, di dalam hadist ada mengatakan disetrika badannya kalau tidak berzakat. Amil yang menyelewengkan hasil dari pengumpulan zakat itu sendiri bisa diganti kaum di Mesjid yang mengelolanya.

Dari penjelasan diatas beliau menjelaskan terkait mengenai kewajiban zakat, khususnya zakat atas hasil pertanian padi kemudian. Selain itu juga diterangkan terkait waktu maupun tempat penyampaiaan pesanpesan Dakwah tersebut kepada masyarakat khususnya masyarakan Anjir Pasar.

Kemudian sebagai seorang Da'i atau Ulama tentu harus sangat mengerti mengenai ketepatan dan kecocokan waktu dan tempat penyampaian suatu pesan-pesan atau materi Dakwah, hal ini tentu sangat mempengaruhi ketepatan hasil yang di izinkan, seperti yang dijelaskan dalam wawancara beliau menjawab: "Macam-macam tentang zakat pertanian, sering disampaikan pada musim-musim panen. Masyarakat anjir berzakat dengan cara langsung mengantar ke fakir miskin, bisa berzakat masingmasing tidak melalui amil". Dalam penjelasan tersebut beliau menyebutkan terkait waktu penyampaiaan pesan atau materi terkait Zakat tersebut.

Dalam pendapat lain menyebutkan bahwa: biasanya menyampaikan tentang apabila sampai nisabnya dan haulnya (harta) wajib zakat, kenapa perlu dismpaikan tentang zakat agar masyarakat sadar pentingnya berzakat. Sudah benar saja cara masyarakat anjir dalam berzakat. Dalam pendapat ini beliau menjelaskan terkait kewajiban mengeluarkan zakat bagi masyarakat khususnya masyarakat Anjir Pasar.

Dalam pendapat lain juga dijelaskan terkait kewajiban berzakat tersebut : "Agar masyarakat yang mampu berzakat kepada orang memerlukannya yaitu orang yang 8 , bagaimana penyaluran dan penggunaan zakatnya. Dan masyarakat tau bagaimana hukum zakat pertanian, kalau secara umum cara masyarakat anjir sudah benar dalam menunaikan zakat pertanian". Dalam wawancara beliau menjelaskan akan kewajiban berzakat oleh masyarakat serta terkait perihal lainnya. Seluruh penyampaian pesanpesn tersebut tentu tidak terlepas dari peran Ulama khususnya Anjir dengan berbagai metode, baik metode Bil lisan ataupun bil Hikmah.

\section{Metode Dakwah Al- Hikmah}

Dakwah AL-Hikmah yakni menyampaikan dakwah dengan cara yang arif bijaksana, yaitu melakukan pendekatan sedemikian rupa sehingga pihak obyek dakwah mampu 
melaksanakan dakwah atas kemauannya sendiri, tidak merasa ada paksaan, tekanan maupun konflik. Dengan kata lain dakwah bi al-hikmah merupakan suatu metode pendekatan komunikasi dakwah yang dilakukan atas dasar persuasif.

Ketika penulis bertanya tentang metode apa saja yang sering disampaikan kepada masyarakat tentang zakat pertanian Ustadz $\mathrm{H}$. Abdullah Syarkawi mejawab: "Masalah pendapatan-pendapatan yang nisabnya berapa, dan padi wajib dizakati sebab zakat itu yang diwajibkan Allah Ta'ala karena termasuk rukun Islam yang ke 5. Masyarakat Anjir dalam menunaikan zakat pertanian ada perbedaan pendapat, kadang-kadang ada yang berlainan cara mengeluarkan zakatnya". Ustadz H. M. Syarkawi masdar beliau menjawab: "Macam-macam tentang zakat pertanian, sering disampaikan pada musim-musim panen. Masyarakat anjir berzakat dengan cara langsung mengantar ke fakir miskin, bisa berzakat masing-masing tidak melalui amil".

Ustadz Ahmad Rafi'i beliau menjawab: "Biasanya menyampaikan tentang apabila sampai nisabnya dan haulnya (harta) wajib zakat, kenapa perlu dismpaikan tentang zakat agar masyarakat sadar pentingnya berzakat. Sudah benar saja cara masyarakat anjir dalam berzakat".

Ustadz H. Rasyidi beliau menjawab: "Agar masyarakat yang mampu berzakat kepada orang memerlukannya yaitu orang yang 8 , bagaimana penyaluran dan penggunaan zakatnya. Dan masyarakat tau bagaimana hukum zakat pertanian, kalau secara umum cara masyarakat anjir sudah benar dalam menunaikan zakat pertanian". Ustadz Norfansyah beliau juga menjawab: "Paling sering menyampaikan tentang kewajiban zakat, dan orang-orang yang menerima zakat. Wajib apabila sudah sampai nisabnya, karena kalau tidak disampaikan tentang penting nya berzakat dikhawatirkan ada yang lalai atau enggan berzakat, seperti yang kita lihat masyarakat anjir berzakat sesuai dengan tuntunan ajaran Islam".

\section{E. PEMBAHASAN}

Setelah menyajikan data sebagai mana yang tertuang pada pembahasan di atas, kemudian penulis menganalisis data tersebut untuk memberikan pandangan bagaimana Dakwah Ulama tentang Zakat Pertanian Pada Masyarakat Kecamatan Anjir Pasar Kabupaten Barito Kuala.

Pandangan ulama yang menjadi responden dalam penelitian terhadap zakat pertanian. Pendapat kelima ulama tentang zakat pertanian yang dikenakan zakat, apabila memenuhi syarat. Para ulama sepakat tentang kewajiban zakat pertanian, karena berdasarkan pada dalil Al-Qur'an dan hadits. Akan tetapi, para ulama di kecamatan Anjir Pasar berbeda pendapat mengenai zakat jenis hasil bumi yang dikenakan zakat.

Menurut ulama di Kecamatan Anjir Pasar yang wajib di zakati adalah padi, jagung dan pada zaman Nabi seperti kurma dan gandum, karena termasuk makanan pokok dan yang dapat di simpan. Sesuai dengan mazhab yang di gunakan para ulama kecamatan Anjir Pasar adalah mazhab Syafi'i. Para ulama mengikuti mazhab syafi'i yang menetapkan bahwa zakat sepersepuluh hanya dikhususkan untuk makanan yang mengenyangkan yakni dari keluarga buah-buahan, biji-bijian dan semua makanan yang mengenyangkan.

Menurut para ulama berzakat langsung kepada mustahik tidak melewati Badan Amil Zakat boleh saja, karena apa yang dikeluarkan diniatkan untuk berzakat, kecuali jika pemerintah menetapkan bahwa seluruh rakyat harus menyetorkan zakat-zakat mereka kepada BAZ (Badan Amil Zakat) yang resmi ditunjuk oleh pemerintah, untuk selanjutkan akan dibagikan kepada yang berhak, maka dalam keadaan seperti ini masyarakat wajib menyerahkan zakat tersebut kepada BAZ sebagai bentuk ketaatan kepada penguasa. Dan perbuatan itu insya Allah tidak teranggap melalaikan 
amanah, karena intinya harta itu akan sampai kepada yang berhak.

Materi dakwah yang disampaikan ulama tentang zakat pertanian di Kecamatan Anjir Pasar adalah masalah pendapatan-pendapatan yang nisabnya berapa apabila sampai nisabnya dan haulnya (harta) wajib zakat, paling sering menyampaikan tentang kewajiban zakat, orang-orang yang berhak menerima zakat. Akan tetapi, berbeda-beda tidak khusus tentang zakat saja yang di sampaikan ulamaulama Kecamatan Anjir Pasar, bisa ceramah masalah sembahyang, melihat situasi yang hadir pembacaan ketika ceramah disampaikan. Pada saat musim panen biasanya ulama sering menyampaikan zakat pertanian dalam kegiatan ceramah-ceramah atau majelis ta'lim.

Dengan adanya ulama ini diharapkan mampu untuk mengkomunikasikan akan pentingnya zakat pertanian. Karena nasehat-nasehat dan petuah yang disampaikan para ulama lebih mudah diterima masyarakat. Metode dakwah ulama yang digunakan tentang zakat pertanian ada bermacam-macam Metode dakwah yaitu Metode Dakwah Al-Hikmah, Metode Dakwah AlMau'idzatil Hasanah dan Metode Dakwah Al-Mujadalah Bil Lati Hiya Ahsan, Dakwah Bil Lisan, Dakwah Bil qolam, Dakwah Bil nikah, Dakwah bil hal, Dakwah Bil maal, Dakwah bil rikhlah, Dakwah Bil-Qolbi. Dari sekian banyak metode dakwah yang disebutkan di atas yang biasanya digunakan Ulama kecamatan Anjir adalah hanya Metode Dakwah Bil Lisan dan Dakwah AL-Hikmah pada saat menyampaikan materi ceramah di berbagai tempat.

Semua Juru Dakwah dalam mengkomunikasikan materi zakat padi menggunakan metode dakwah bil lisan yaitu ceramah-ceramah, khotbah jum'at, acara-acara pengajian tempatnya di mesjid, musholla, dan undangan-undangan di rumah masyarakat. Metode face to face cara yang sering digunakan para ulama.
Metode dakwah yakni menyampaikan dakwah dengan cara yang arif bijaksana, yaitu melakukan pendekatan sedemikian rupa sehingga pihak obyek dakwah mampu melaksanakan dakwah atas kemauannya sendiri, tidak merasa ada paksaan, tekanan maupun konflik. Dengan kata lain dakwah bi al-hikmah merupakan suatu metode pendekatan komunikasi dakwah yang dilakukan atas dasar persuasif.

\section{F. KESIMPULAN}

Berdasarkan data yang telah disajikan dalam karya tulis ini mengenai Dakwah Ulama tentang Zakat Pertanian di Kecamatan Anjir Pasar Kabupaten Barito Kuala, dapat diambil kesimpulan sebagai berikut:

1. Para ulama sepakat bahwa zakat pertanian, khususnya padi, hukumnya adalah wajib. Tetapi mereka berbeda pendapat tentang jumlah belik padi yang wajib dizakati. Sebagian berpendapat apabila padi sudah sampai 100 belik maka wajib dizakati. Yang lainnya berpendapat kalau padi sudah sampai 85 belik maka wajib dizakati. Kemudian ada juga yang berpendapat bahwa kalau padi sudah sampai 84 belik baru wajib dizakati. Namun mereka semua berpendapat bahwa jumlah zakat yang dikeluarkan adalah $10 \%$.

2. Materi Dakwah yang disampaikan para Ulama di Kecamatan Anjir Pasar tentang zakat pertanian tidak terlepas dari hukum-hukumnya serta bagianbagiannya, seperti takaran wajib pemberian zakat ataupun orang-orang yang berhak menerima zakat tersebut. Terkait materi tersebut, kemudian beberapa ulama juga menjelaskan bahwa selain menyampaikan materi terkait zakat pertanian, mereka juga menyampaikan materi-materi yang lain, seperti kewajiban sholat dan lain-lain.

3. Metode dakwah para Ulama dalam penyampaian materi tentang zakat pertanian tersebut biasanya dilaksanakaan oleh para ulama dengan dua metode yang digunakan yaitu metode dakwah bil lisan dan dakwah bil 
Hikmah. Dakwah bil lisan seperti ceramah mingguan ataupun bulanan biasanya dilakukan oleh Ulama dalam kesempatan tertentu seperti pengajian rutin, majelis ta'lim maupun undanganundangan acara di masyarakat. Selain itu dalam acara-acara besar tentu juga diisi dengan ceramah-ceramah agama. Dalam kesempatan lain juga disampaikan materi dakwah dengan metode bil lisan seperti dalam Khutbah Jum'at.

\section{DAFTAR PUSTAKA}

Abda, Slamet Muhaimin, Prinsip prinsip Metodologi Dakwah. Surabaya, AlIkhlas, 1994.

Al-Ghazali, Rahasia Puasa dan Zakat. Bandung, Kharisma, 1993.

Az-Zuhaili, Wahbah, Fiqih Zakat dalam Dunia Modern. Surabaya, Bintang, 2001.

Bakry, Nazar, Problematika Pelaksanaan Fiqh Islam. Jarkata, Raja Grafindo Persada.

Enjang As, et al., Dasar-dasar Ilmu Dakwah. Bandung, Widya Padjajaran, 2009.

Faisal, Sanafiah, Format-Format Penelitian Sosial. Jakarta, PT. Raja Grafindo, 2005.

Gustian, Djuanda, Pelaporan Zakat Pengurang Pajak Penghasilan.
Jakarta, PT RajaGrafindo Persada, 2006.

Makkie, H.A, Ulama Kalimantan Selatan Dari Masa ke Masa. Banjarmasin, Majelis Ulama Indonesia, 2010.

Habsy Ash Syiddieyqy, Muhammad, Pedoman Zakat. Semarang, PT.Pustaka Rizki Putra, 1997.

Hasan, M. Ali, Zakat dan Infak. Jakarta, Kencana, 2006.

Helmy, Masdar, Memahami Zakat dan Cara Menghitungnya. Bandung, PT Alma'arif, 2001.

Munir, M, et al., Manajemen Dakwah. Jakarta, Kencana, 2006.

Nasution, Harun, Islam Rasional Gagasan dan Pemikirannya. Bandung, Mizan, 1989.

Qardhawiyah, Yusuf Al, Figh Al Zakat Jilid I. Beirut, Muassasah Al Risalah, 1991.

Latief, Rowi Moh, et al., Tuntunan Zakat Praktis. Surabaya, Indah, 1997.

Subandi, Ahmad, Ilmu Dakwah pengantar Kearah Metodologi. Bandung, Yayasan Syahida, 1994.

Sudirman, MA, Zakat dalam Pusaran Arus Modernitas. Malang, UIN Malang, 2007.

Wahyu, Ilaihi, Komunikasi Dakwah. Bandung, PT Remaja Rosdakarya, 2010. 